\title{
Development of a convenient detection method for Trichomonas vaginalis based on loop-mediated isothermal amplification targeting adhesion protein 65
}

Yuhua Li†, Shuai Wang ${ }^{\dagger}$, Haoran Li, Xiaoxiao Song, Hao Zhang, Yujuan Duan, Chengyang Luo, Bingli Wang, Sifan Ji, Qing Xie and Zhenchao Zhang ${ }^{*}$ (i)

\begin{abstract}
Background: Trichomoniasis resulting from Trichomonas vaginalis (T. vaginalis) has been considered as a commonly seen disease with the transmission way of sex. At present, the detection methods of $T$. vaginalis mainly include wet mount microscopy, culture, PCR, immunofluorescence and ELISA. However, all of these detection methods exist shortcomings.

Methods: In this study, a loop-mediated isothermal amplification (LAMP) assay that targeted the species-specific sequence of adhesion protein 65 (AP65) gene had been conducted to detect T. vaginalis. The optimum reaction system and conditions were optimized in this rapid detection method.

Results: The results of sensitivity analysis showed that the LAMP assay targeting the AP65 gene was 1000 times more sensitive than the nested PCR targeting the actin gene commonly used for detection of T. vaginalis, and the detecting limitation of the former was 10 trichomonad. Moreover, the amplification of the target gene AP65 by LAMP assay exhibited high specificity and the product was exclusively from $T$. vaginalis. The detection technique of LAMP did not exhibit cross-reactivity with the common pathogens of Trichinella spiralis, Toxoplasma gondii,

Escherichia coli, Candida albicans, Staphylococcus aureus, Haemophilus.

Conclusions: According to the present study, the LAMP assay with the target of AP65 gene, was suitable for the early diagnosis of $T$. vaginalis infections. Consequently, the LAMP assay was proposed by the current study as a point-of-care examination and an alternative molecular tool which exhibited the potential value in the treatment, control and prevention of trichomoniasis transmission and relevant complication.
\end{abstract}

Keywords: Trichomonas vaginalis, Adhesion protein 65, LAMP, Diagnosis, Analytical sensitivity and specificity

\section{Background}

Trichomoniasis, which is resulting from $T$. vaginalis, a kind of protozoa with flagella, has been considered as a

\footnotetext{
*Correspondence: zhangzhenchao525@163.com

${ }^{\dagger}$ Yuhua Li and Shuai Wang contributed equally to this work.

Xinxiang Key Laboratory of Pathogenic Biology, School of Basic Medical Sciences, Xinxiang Medical University, Xinxiang, Henan 453003, People's Republic of China
}

commonly seen curable disease with the transmission approach of sex and the quantity of affected people all around the world reaches 276.4 million $[1,2]$. T. vaginalis is parasitized in the vagina and urethra of female, and in the urethra and prostate gland of male $[3,4]$. The disease is characterized by asymptomatic status with the pathogen and acute or chronic inflammation [5]. As an extracellular parasite, $T$. vaginalis adheres to the surface

(c) The Author(s). 2020 Open Access This article is licensed under a Creative Commons Attribution 4.0 International License, which permits use, sharing, adaptation, distribution and reproduction in any medium or format, as long as you give appropriate credit to the original author(s) and the source, provide a link to the Creative Commons licence, and indicate if changes were made. The images or other third party material in this article are included in the article's Creative Commons licence, unless indicated otherwise in a credit line to the material. If material is not included in the article's Creative Commons licence and your intended use is not permitted by statutory regulation or exceeds the permitted use, you will need to obtain permission directly from the copyright holder. To view a copy of this licence, visit http://creativecommons.org/licenses/by/4.0/ The Creative Commons Public Domain Dedication waiver (http://creativecommons.org/publicdomain/zero/1.0/) applies to the data made available in this article, unless otherwise stated in a credit line to the data. 
of epithelial cells, and the damage to epithelial cells mainly depends on direct contact [6]. The wound of the parasitic site of epithelial cells was caused by the mechanical action of pleomorphic pseudopodia of trophozoite passing through and wrapping and flagellum movement, the digestion of releasing hydrolase, phagocytosis, and complex effects of exfoliative factors, after $T$. vaginalis infected human reproductive urinary tract. Then inflammation of tissues and organs was caused $[7,8]$.

According to statistics, more than 170 million people were infected with the disease every year in the world, and the infection rate of people around the world was different and had an increasing trend [9]. In the United States, nearly 5 million people were infected with $T$. vaginalis every year, while the infection rate was $24.3 \%$ in Japan, $23.8 \%$ in Uganda and $18.0 \%$ in South Africa [10]. In China, the infection rate in different places and people fluctuated greatly, ranging from a few percent to dozens of percent [11-13]. Clinical manifestations of the disease in women possibly contain vulvovaginal irritation, lower abdominal pain, dyspareunia, dysuria, malodorous vaginal discharge $[2,14]$, although the infection is usually asymptomatic in men or in a few cases with the clinical manifestations of dysuria, irritation, urethral discharge $[15,16]$. In addition, pregnant women infected with $T$. vaginalis could cause decrease of birth weights, premature rupture of fetal membrane, premature delivery, abortion [17]. Recent studies have shown that $T$. vaginalis infection is also related to cervical cancer in women [18], prostate cancer in men and infertility [18, 19]. The widespread infection and prevalence of $T$. vaginalis increased the risk of human infection with human immunodeficiency virus (HIV) and mycoplasma, and $T$. vaginalis has become an important co-factor of HIV infection [20].

The accurate diagnosis of trichomoniasis is an important link in the prevention and treatment of the disease, and it is of great significance to prevent the transmission of the disease. At present, the detection methods of $T$. vaginalis mainly contain wet mount microscopy, PCR, culture, immunofluorescence as well as ELISA [21, 22]. Among the diagnostic methods, the wet mount microscopy is low in cost, but poor in sensitivity [23]. The method of culture $T$. vaginalis is widely recognized as the "gold standard" for diagnosing trichomoniasis [24]. The sensitivity of the diagnostic method is high, but it takes a long time and requires high quality specimens, and microscopic examiner needs to be professional and experienced. PCR detection is highly sensitive and specific, but it relies on the expensive instrument, and the amplified products need to be analyzed by gel electrophoresis [25]. The fluor immunofluorescence and ELISA are sensitive, but the specificity is poor, and the cost of antibody is expensive, and the detection time is long
[26]. In 2000, Notomi et al. established LAMP technology, which had the advantages of simplicity, rapidity, high sensitivity, strong specificity and low cost [27]. The technology could amplify a large number of target genes in a short time and isothermal condition. In addition, this technology has been applied to the detection of bacteria, viruses and other pathogens [28].

AP65, as a specific protein of T. vaginalis, is a dominant functional protein which is targeted both to the surface and hydrogenosomes, and mediate binding to host cells $[29,30]$. Garcia et al. indicated that TvAP65 was a prominent adhered protein of trichomonad compared to other adhesin, and the protein was the hydrogenosomal NAD-dependent decarboxylating malic enzyme [31]. In this study, we developed a novel way to detect $T$. vaginalis based on loop-mediated isothermal amplification targeting adhesion protein 65 .

\section{Methods \\ Parasites}

In the current work, the strain of $T$. vaginalis was isolated from the vaginal secretions of female patients clinically exhibiting certain trichomoniasis symptoms in the Third Affiliated Hospital of Xinxiang Medical University. The culture of T. vaginalis was performed using $10 \%$ calf serum, TYM medium added with antibiotics $(100 \mathrm{mg} / \mathrm{ml}$ ceftriaxone, $50 \mathrm{mg} / \mathrm{ml}$ ciprofloxacin), fungicides $(2.5 \mathrm{mg} /$ $\mathrm{ml}$ amphotericin $\mathrm{B}$ ) in a humidified chamber containing $5 \% \mathrm{CO}_{2}$ at $37^{\circ} \mathrm{C}$. The stationary phase parasites $\left(2 \times 10^{6}\right.$ parasites) were collected using a centrifuge and used subsequently in the experiments.

\section{DNA extraction of $T$. vaginalis}

PBS ( $\mathrm{pH} 7.2$ ) was used to wash the T. vaginalis trophozoite for thrice, which was subsequently isolated by centrifugation under the velocity of $5000 \mathrm{rpm}$ for 5 minutes and subjected to DNA extraction using commercial kits (OMEGA) in accordance with the instruction.

The DNA simple of Trichinella spiralis, Toxoplasma gondii, Escherichia coli, Candida albicans, Staphylococcus aureus, Haemophilus were stored in Xinxiang Key Laboratory of Pathogenic Biology.

\section{Detection of actin gene from $T$. vaginalis using nest-PCR}

DNA extracts were subjected to species-specific nested PCR for T. vaginalis actin (GenBank Accession No. AF237734). Briefly, the primary PCR was performed in a $25 \mu \mathrm{L}$ reaction mixture consisting of $12.5 \mu \mathrm{L}$ of $2 \times \mathrm{PCR}$ Master Mix (YIFEI XUE BIOTECHNOLOGY, Nanjing, China), $1 \mu \mathrm{L}(0.1 \mu \mathrm{mol} / \mathrm{L})$ each of the primers OUT-F and OUT-R (Table 1), $1.0 \mu \mathrm{L}$ of DNA template (100$200 \mathrm{ng}$ ), and $9.5 \mu \mathrm{L}$ of double distilled water. The procedures and conditions of amplifying DNA included: 3 minutes at $95^{\circ} \mathrm{C}$ for denaturation, $95^{\circ} \mathrm{C}$ for $45 \mathrm{~s}, 55^{\circ} \mathrm{C}$ for 
Table 1 Oligonucleotide primer sequences used for Nested PCR in this research

\begin{tabular}{lll}
\hline Name & Sequences(5'-3') & Description \\
\hline OUT-F & TCTGGAATGGCTGAAGAAGACG & Forward primer for the actin gene of T. vaginalis in the first stage \\
OUT-R & CAGGGTACATCGTATTGGTC & Reverse primer for the actin gene of $T$. vaginalis in the first stage \\
IN-F & CAGACACTCGTTATCG & Forward primer for the actin gene of $T$. vaginalis in the second stage \\
AP65-FIP & CGGTGAACGATGGATG & Reverse primer for the actin gene of $T$. vaginalis in the second stage \\
AP65-BIP & GCCGACATAGAAGGATGGGA & Forward inner primer for the AP65 gene of $T$. vaginalis in LAMP assay \\
AP65-F3 & CCTCCACTCACCCTCTGGCCGTACAA & \\
AP65-B3 & ACTGTGGGGAACACCAT & Backward inner primer for the AP65 gene of T. vaginalis in LAMP assay \\
\hline
\end{tabular}

$30 \mathrm{~s}$, and $72{ }^{\circ} \mathrm{C}$ for $1 \mathrm{~min}$ through 35 cycles, and $72{ }^{\circ} \mathrm{C}$ for $10 \mathrm{~min}$ for final extension. Then the second PCR was performed as the primary $\mathrm{PCR}$, and $1.0 \mu \mathrm{L}$ the products of primary PCR and $1 \mu \mathrm{L}(0.1 \mu \mathrm{mol} / \mathrm{L})$ each of the primers IN-F and IN-R (Table 1) were used as template and primers in this reaction. Electrophoresis using 1.5\% agarose stained by $1.0 \mu \mathrm{L}$ of Goldview Safe DNA Gel Stain (Yifei Xue Biotechnology, Nanjing, China) in advance was used to resolve the obtained DNA sequences at $100 \mathrm{~V}$ and a UV transilluminator (UVP, Upland, CA, USA) was used to visualize the bands.

\section{Designing the primers of LAMP}

LAMP Designer version 1.02 (Premier Biosoft, Palo Alto, CA, USA) was used to design the specific LAMP primers of $T$. vaginalisAP65 on the basis of the sequence in NCBI (GenBank Accession No. U35243.1). Four primers including outer primers (AP65-F3, AP65-B3), inner and forward primers (AP65-BIP, AP65-FIP) were chosen (Table 1). BLAST search was used to assess the specificity of these primers towards the sequences of target genes recorded by NCBI (http://www.blast.ncbi.nlm.nih. gov).

\section{Detection of AP65 gene of $T$. vaginalis by LAMP assays}

The mixed reaction solution with the volume of $20 \mu \mathrm{L}$ which contained Betaine $(5 \mathrm{M}) 6 \mu \mathrm{L}$ (Sigma, St. Louis, MO, USA), $10 \times$ Bst DNA polymerase Buffer $2 \mu \mathrm{L}$, dNTPs Mixture (10 mM each) $2 \mu \mathrm{L}$, each of AP65-FIP and AP65-BIP $(16 \mu \mathrm{M}) 1 \mu \mathrm{L}$, each of F3 and B3 $(4 \mu \mathrm{M})$ $1 \mu \mathrm{L}, \mathrm{MgCl}_{2}(25 \mathrm{mM}) 3 \mu \mathrm{L}, 8.0 \mathrm{U}$ Bst DNA polymerase (TaKaRa, Dalian, China) $1.5 \mu \mathrm{L}$, and $\mathrm{ddH}_{2} \mathrm{O} 1.5 \mu \mathrm{L}$ was used to perform the LAMP assays. The temperature condition of the LAMP reaction system was $63^{\circ} \mathrm{C}$ for 120 min during the incubation and $80^{\circ} \mathrm{C}$ for $10 \mathrm{~min}$ during the termination in a heating block. The experiment contained negative control $\left(\mathrm{ddH}_{2} \mathrm{O}\right)$ and positive control (T. vaginalis DNA).

The LAMP products were assessed by gel electrophoresis and addition of SYBR GreenI(Solarbio, Beijing,
China). For gel electrophoresis, $1.5 \%$ agarose gel was used to resolve $5.0 \mu \mathrm{L}$ of the product of LAMP, as mentioned above, and the positive result was indicated by the pattern of bands like ladders. For addition of SYBR GreenI, $2.0 \mu \mathrm{L}$ of $1000 \times$ SYBR GreenIwas added to the remainder $15 \mu \mathrm{L}$ of LAMP products, and the positive result was revealed by dull to fluorescent signal or change of colors from orange to green under visible light.

\section{Analytical sensitivity of detection of AP65 gene of $T$. vaginalis by LAMP assay}

The DNA with the initial concentration of $90 \mathrm{ng} / \mu \mathrm{L}$ was diluted by $10^{1}-10^{12}$ times and kept for use. The trophozoites of $T$. vaginalis were diluted to $10^{3}, 10^{2}, 10^{1}$ and 1 respectively, and the DNA of these diluted samples was extracted. Then, the prepared DNA samples were amplified by nested PCR and LAMP respectively, as described above. All the experiments were conducted in triplicate independently.

\section{Analytical specificity of detection of AP65 gene of $T$. vaginalis by LAMP assay}

The examination of the analytical specificity of AP65 gene of $T$. vaginalis by LAMP assay was conducted for determining the cross-reactive degree among DNA extraction samples from various trichomonads, Trichinella spiralis, Toxoplasma gondii, Escherichia coli, Candida albicans, Staphylococcus aureus and Haemophilus with close relation. The experiment contained negative control $\left(\mathrm{ddH}_{2} \mathrm{O}\right)$ and positive control ( $T$. vaginalis DNA). All the experiments were conducted in triplicate independently.

\section{Results}

\section{Detecting $T$. vaginalis by nested PCR and LAMP}

T. vaginalis actin gene was amplified using nest PCR with specific primers, and a positive sequence of about $1100 \mathrm{bp}$ was obtained in line 3 and 4 with the expectation (Fig. 1a). There were no target amplicons in 


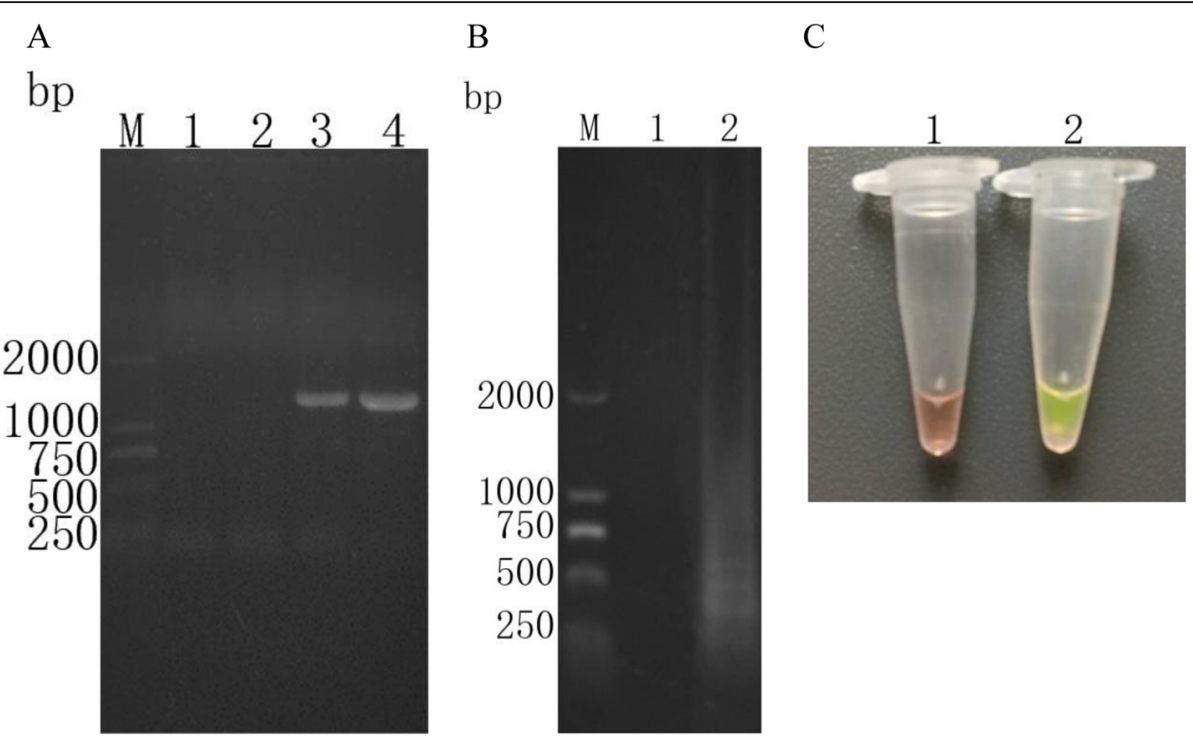

Fig. 1 Detection of T. vaginalis with amplification of actin gene by nested PCR and AP65 gene by LAMP. a: Agarose gel electrophoresis of nested PCR products. (Lane M) DL 2000 the DNA molecular weight marker (ordinate values are expressed in bp); (Lane 1) Negative control outer amplification products; (Lane 2) Negative control inner amplification products; (Lane 3) T. vaginalis DNA outer amplification products; (Lane 4) T. vaginalis DNA inner amplification products. b: Agarose gel electrophoresis of LAMP products. (Lane M) DL 2000 the DNA molecular weight marker (ordinate values are expressed in bp); (Lane 1) Negative control LAMP products; (Lane 2) T. vaginalis DNA LAMP products; c: LAMP products detected by addition of SYBR Greenl. (Lane 1) Negative control LAMP products (orange); (Lane 2) T. vaginalis DNA LAMP products (green)

negative controls. The products of nest PCR were further confirmed by sequence analysis.

According to the results of electrophoresis, the products amplified by LAMP with the target of AP65 in $T$. vaginalis exhibited distinctive pattern of multiple bands (Fig. 1b). An orange-to-green color change was observed under natural light or a dull to fluorescent signal under UV transilluminator, after addition of SYBR GreenI(Fig. 1c).

\section{The analytical sensitivity of $T$. vaginalis nested PCR and LAMP}

The initial concentration of $90 \mathrm{ng} / \mu \mathrm{L}$ of $T$. vaginalis DNA was diluted by $10^{1}-10^{12}$ times. As shown in Fig. 2, the lowest template concentration was $90 \times 10^{-7} \mathrm{ng} / \mu \mathrm{L}$ detected by nested PCR (Fig. 2a), while that was $90 \times$ $10^{-10}$ detected by LAMP amplification (Fig. $2 \mathrm{~b}$ and c). It could be seen that the analytical sensitivity of LAMP assays of T. vaginalis established in this study was 1000 times higher than that of nested PCR.

In order to further explore the sensitivity of LAMP amplification, the trophozoites of $T$. vaginalis were diluted to $10^{3}, 10^{2}, 10^{1}$ and 1 respectively, and the DNA of these diluted samples was extracted. These results were shown that $10^{3}$ trophozoites of $T$. vaginalis could be detected by nested PCR (Fig. 3a), while 10 trophozoites of T. vaginalis could be detected by LAMP amplification (Fig. $3 \mathrm{~b}$ and $\mathrm{c}$ ).

\section{The analytical specificity of LAMP for $T$. vaginalis}

There were no cross reactions in the LAMP using DNA extractions from $T$. vaginalis and other microorganisms including Trichinella spiralis, Toxoplasma gondii, Escherichia coli, Candida albicans, Staphylococcus aureus and Haemophilus. There were objective bands exclusively in experiments using DNA from $T$. vaginalis, either the results were observed under visible light by adding SYBR GreenIor using a UV transilluminator (Fig. 4).

\section{Discussion}

As a kind of protozoan parasite that infects the genitourinary system of human beings, $T$. vaginalis is found worldwide but receives less attention compared to other agents of STIs such as Neisseria gonorrhoeae and Chlamydia trachomatis [32-35]. From 2011 to 2014, the T. vaginalis prevalence in Granada, a capital city in Southern Spain was 2.4\% [36]. According to the results of a cross-sectional research in a city attached to Yunnan Province, southern China, the $T$. vaginalis prevalence was $9.0 \%$ among 734 female sex workers [37]. In addition, according to an observation conducted in Xinxiang of Henan Province, China, 267 of 16,294 (1.64\%) samples from female patients suffering from certain trichomoniasis symptoms exhibited clinical positive results under wet mount microscopy [11]. 


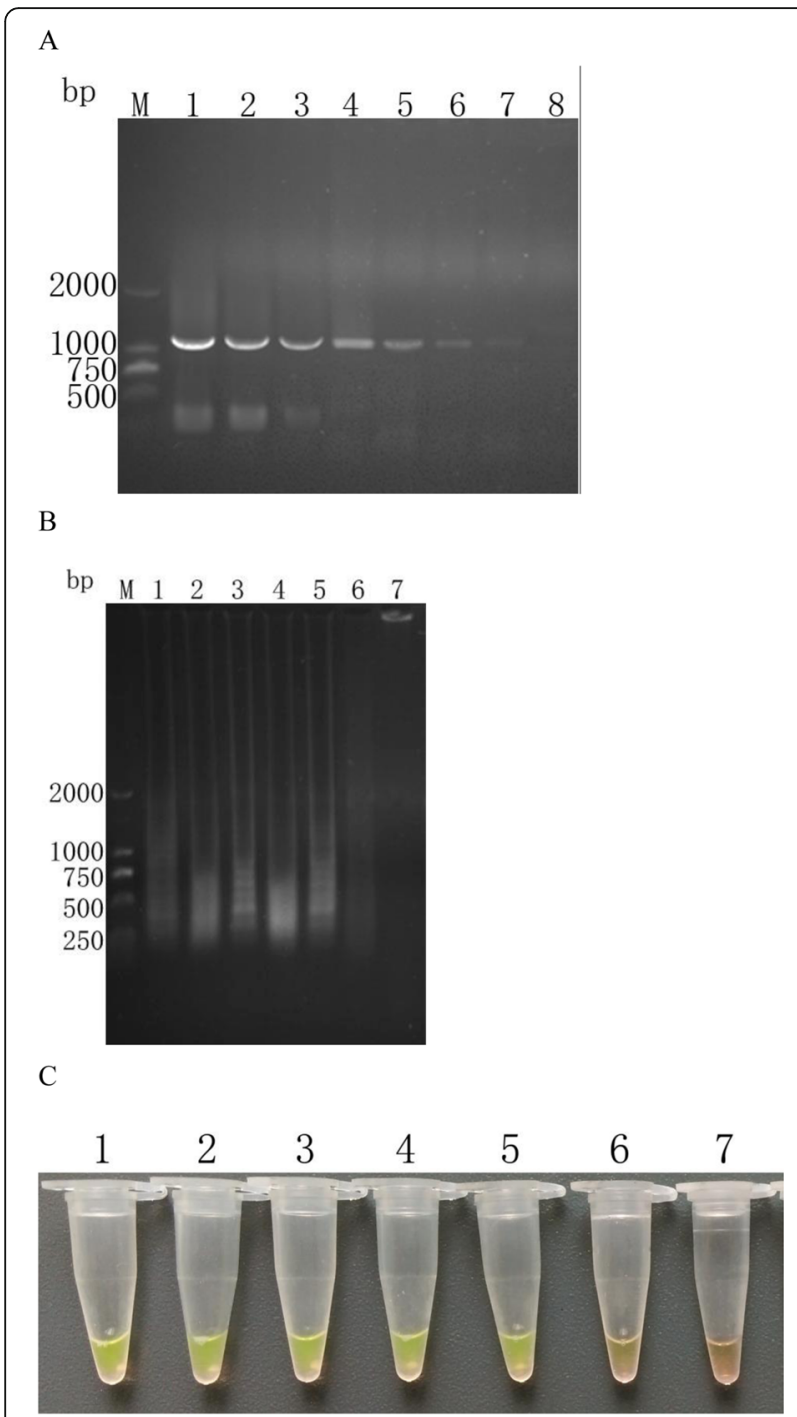

Fig. 2 Compare sensitivity of detection of T. vaginalis by nested PCR and LAMP with gradient dilution of T. vaginalis DNA template. a: Agarose gel electrophoresis of inner amplification products.(Lane M) DL 2000 the DNA molecular weight marker (ordinate values are expressed in bp); (Lane 1-8) The initial concentration of $90 \mathrm{ng} / \mu \mathrm{L}$ of T. vaginalis DNA was diluted by $10^{1}-10^{8}$ times, amplified by outer amplification, and then amplified by inner amplification. b: Agarose gel electrophoresis of LAMP products. (Lane M) DL 2000 the DNA molecular weight marker (ordinate values are expressed in bp); (Lane 1-7) The initial concentration of $90 \mathrm{ng} / \mathrm{\mu L}$ of T. vaginalis DNA was diluted by $10^{6}-10^{12}$ times. c: LAMP products detected by addition of SYBR Greenl. (Lane 1-7) The initial concentration of 90 $\mathrm{ng} / \mathrm{\mu L}$ of $T$. vaginalis DNA was diluted by $10^{6}-10^{12}$ times

Accurate and rapid diagnosis of trichomoniasis is the key process of treatment, prevention and blocking transmission. However, there are disadvantages in the existing diagnostic methods [14]. In this study, the developed LAMP assay was a rapid and handy way to detect $T$. vaginalis with high analytical sensitivity and specificity, which was verified as superior to traditional nested PCR.

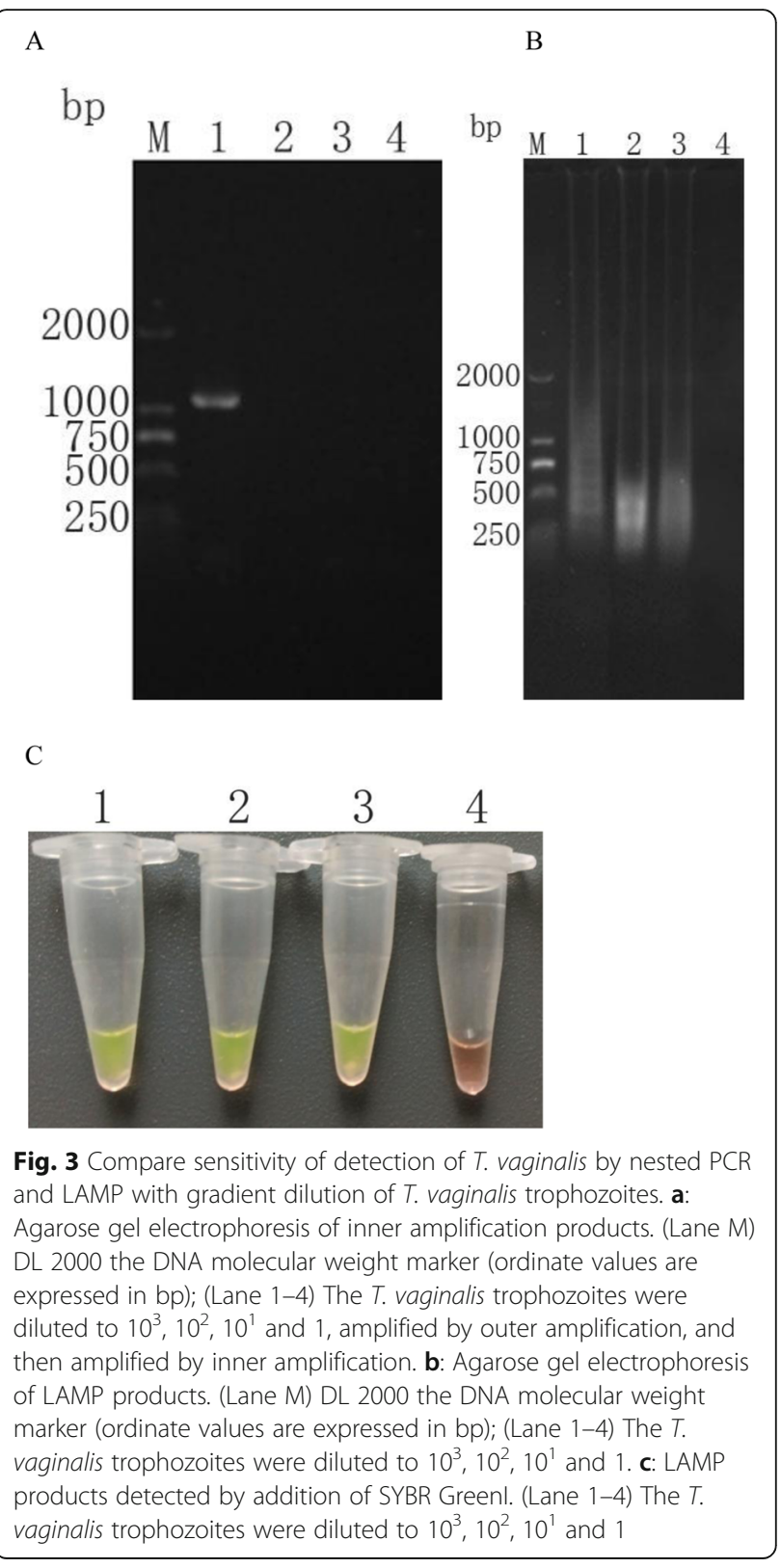

Complicated equipment like thermal cycler was not necessary for LAMP, which could be conducted using hot water bath or common heating block. Moreover, the time for producing $10^{9}$ target gene copies by the LAMP assay was no more than $3 \mathrm{~h}$, which could be reduced by half through the usage of additional loop primers, which was perfect for the point-of-care examinations demanding rapidness [27]. It was revealed by an orange-to-green color change due to adding SYBR GreenIthat large quantity of target gene copies were amplified successfully using LAMP [38]. The LAMP has been considered as a tool of cost-efficiency and rapidness for detecting numerous infections like HIV and malaria, although the 


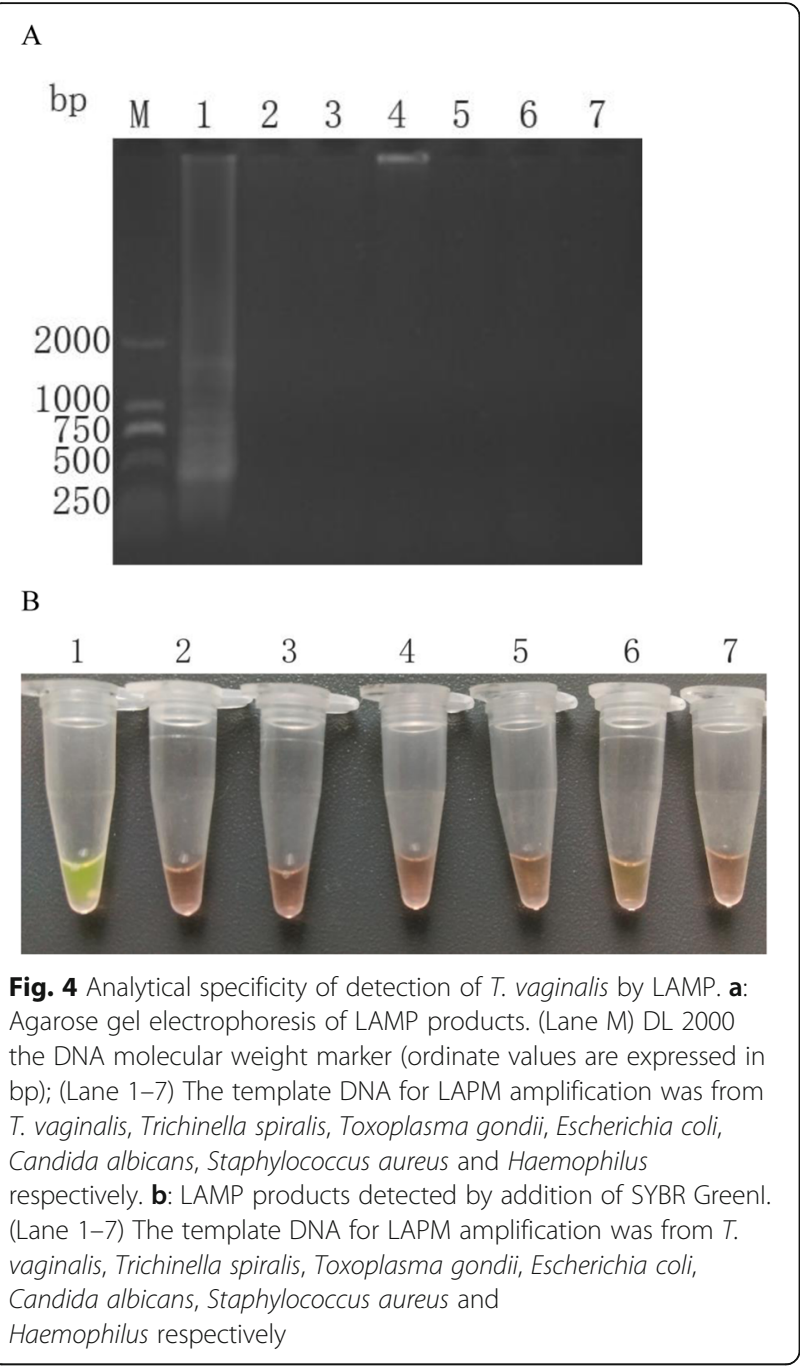

potential value of which in detecting $T$. vaginalis hasn't been developed up to now [39].

Previous researches have shown that LAMP has a 10 to 1000 fold lower limit of detection compared to conventional PCR [40-42]. A LAMP assay designed to detect Cyrptosporidium parvum was even proven to have a 100,000 fold lower limit of detection compared to PCR [43]. The LAMP assay exhibited 1000 times higher sensitivity than the nested PCR in amplifying target genes of $T$. vaginalis. According to the results, the detecting limitation of LAMP was 10 trophozoites of $T$. vaginalis and that of nested PCR was as many as $10^{3}$, and the difference was possibly due to the Bst DNA polymerase which was highly tolerate to inhibitors of nucleic acid amplification tests. Toye et al. indicated that PCR was rarely inhibited using urine specimens, infrequently inhibited using endocervical swabs while frequently inhibited using urethral swabs [44]. Although the inhibiting effect could be reduced by various preparing approaches, it is not sufficient to eliminate the inhibitors of PCR from genital swabs by boiling the specimens. Moreover, for LAMP there was no decrease of signal intensity up to 100 trichomonads $/ \mathrm{mL}$ and the bands in gel with stains of SYBR Safe exhibited typical ladder-like pattern, possibly resulting from significantly higher amplifying product quantity in comparison to that of PCR [38]. As complicated body fluid, urine and genital secretion had been applied to detecting $T$. vaginalis on the basis of nucleic acid, and the sensitivity of which were $64-100 \%$ for urine samples and $81-100 \%$ to genital secretion swabs $[45,46]$. Previous studies have shown that LAMP reactions were not inhibited in spiked urine specimens [47]. Nevertheless, due to the usage of the wild type enzyme in the LAMP approach, unwanted activity of DNA polymerase in the process of setup possibly led to fail in reproducible amplification. In order to solve this problem, a warm start strand-displacing DNA polymerase which kept stable under ambient temperature while didn't work until $50^{\circ} \mathrm{C}$ was used by Tanner et al. [48]. In our study, the time cost for performing LAMP of $T$. vaginalis with high analytical sensitivity from preparing samples to detecting LAMP products was no longer than 130 min.

Although some studies showed that LAMP could detect trichomonad based on target genes of actin, $18 \mathrm{~S}$ rRNA and the 2-kbp repeated DNA, these genes have relatively high homology among different species [4951]. AP65 is a prominent adhesin of $T$. vaginalis that mediates binding of parasites to host vaginal epithelial cells (VECs) [52]. We found that the sequences of AP65 had almost no homology with other species. Accordingly, AP65 as the target gene for detection possessed excellent specificity. In this current study, the LAMP of $T$. vaginalis was highly specific without crossreactivity to trichomonads of human beings with close relationship, such as Trichinella spiralis, Toxoplasma gondii, Escherichia coli, Candida albicans, Staphylococcus aureus and Haemophilus. Many previous studies shown that 6 primers were used for LAMP amplification of target genes $[53,54]$. However, in the research, the 4 primers that recognized 6 instinct sites of the target gene led to the high specificity of LAMP, and AP65 gene could be detected specifically and sensitively without primers LF and LB. Therefore, the AP65 gene of T. vaginalis which was selected as the target gene for conducting highly specific LAMP could be used in the diagnosis of trichomoniasis $[55,56]$.

Nevertheless, there are a few shortages of LAMP. In spite of the high sensitivity and specificity, it is possible for the large quantity of DNA sequences obtained through the experiment to be contaminated by the opened tubes, which results in fault-positive consequences. In most cases, staining materials of nucleic acids, such as SYBR GreenIand Pico Green, are used in 
LAMP for detecting the product, while these materials exert an inhibiting effect on the amplifying process of LAMP. In addition, more than $1 \%$ contamination of biological substances such as blood and urine or more than $30 \%$ of saline solution or PBS can inhibit LAMP as well as PCR reactions [57]. Raw milk contaminants can even inhibit LAMP but not PCR. Consequently, using a realtime turbimeter to monitor the reaction in close tubes [38], using hydroxylnaphthol blue dye added in advance to conduct colorimetric determination [58], or adding wax barrier to SYBR GreenI [59] are capable of preventing contamination due to opened tubes for visualizing endpoint results of LAMP.

\section{Conclusions}

The LAMP assay of T. vaginalis based on AP65 gene in the current work is convenient, specific, sensitive, and rapid way to detect trichomoniasis. However, this is a basic research, and more studies are needed in the future for verifying the diagnosing value of the LAMP assay of T. vaginalis in clinic. The valid and costeffective nucleic acid amplification test exhibits a promising potential in accurately diagnosing, extensively monitoring, effectively controlling and screening trichomoniasis in resourcelimited and point-of-care settings.

\section{Abbreviations}

TV: Trichomonas vaginalis (T. vaginalis); LAMP: Loop-mediated Isothermal Amplification; AP65: Adhesion Protein 65; PCR: Polymerase Chain Reaction; HIV: Human Immunodeficiency Virus; PBS: Phosphate Buffer Saline; ELISA: Enzyme Linked Immunosorbent Assay; TYM: Trypticase Yeast extract Maltose; NCBI: National Center for Biotechnology Information.

\section{Acknowledgements}

Not applicable.

\section{Authors' contributions}

YHL and ZCZ conceived and designed the experiments. $\mathrm{HZ}$ and $\mathrm{YD}$ isolated and cultured the strain of $T$. vaginalis from the vaginal secretions. CYL and BLW extracted the DNA from T. vaginalis trophozoite. SFJ and QX performed nest-PCR. ZCZ designed the primers of LAMP. HRL and XXS performed LAMP. YHL and SW analyzed the data. ZCZ and YHL prepared the figures and tables. YHL wrote the paper. All authors read and approved the final manuscript.

\section{Funding}

This study was funded by the National Natural Science Foundation of China (No. 81802028) and the Doctoral Scientific Research Activation Foundation of Xinxiang Medical University (No. XYBSKYZZ201631 and XYBSKYZZ201504). The funders had no role in study design, data collection and analysis, decision to publish, or preparation of the manuscript.

\section{Availability of data and materials}

All of the data in the present research are contained in the article.

\section{Ethics approval and consent to participate}

The study was reviewed and approved by the Ethics Review Committee of the Xinxiang Medical University (Reference No. 2015016). The participants agreed that the vaginal secretions were used for this study and signed a consent form.

\section{Consent for publication}

Not applicable.

\section{Competing interests}

The authors declare that they have no competing interests.

Received: 12 February 2020 Accepted: 23 April 2020

Published online: 01 May 2020

\section{References}

1. Wiringa AE, Ness RB, Darville T, Beigi RH, Haggerty CL: Trichomonas vaginalis, endometritis and sequelae among women with clinically suspected pelvic inflammatory disease. Sex Transm Infect 2019.

2. Van Gerwen OT, Muzny CA: Recent advances in the epidemiology, diagnosis, and management of Trichomonas vaginalis infection. F1000Research 2019, 8.

3. Harp DF, Chowdhury I. Trichomoniasis: evaluation to execution. Eur J Obstet Gynecol Reprod Biol. 2011;157(1):3-9.

4. Kim JH, Moon HS, Kim KS, Hwang HS, Ryu JS, Park SY. Comparison of Seropositivity to Trichomonas vaginalis between men with prostatic tumor and Normal men. Korean J Parasitol. 2019;57(1):21-5.

5. Kim SS, Kim JH, Han IH, Ahn MH, Ryu JS. Inflammatory responses in a benign prostatic hyperplasia epithelial cell line (BPH-1) infected with Trichomonas vaginalis. Korean J Parasitol. 2016;54(2):123-32.

6. Nievas YR, Coceres VM, Midlej V, de Souza W, Benchimol M, Pereira-Neves A Vashisht AA, Wohlschlegel JA, Johnson PJ, de Miguel N. Membrane-shed vesicles from the parasite Trichomonas vaginalis: characterization and their association with cell interaction. CMLS. 2018;75(12):2211-26.

7. Chen YP, Riestra AM, Rai AK, Johnson PJ: A Novel Cadherin-like Protein Mediates Adherence to and Killing of Host Cells by the Parasite Trichomonas vaginalis. mBio 2019, 10(3).

8. Hinderfeld AS, Phukan N, Bar AK, Roberton AM, Simoes-Barbosa A Cooperative Interactions between Trichomonas vaginalis and Associated Bacteria Enhance Paracellular Permeability of the Cervicovaginal Epithelium by Dysregulating Tight Junctions. Infect Immun. 2019;87(5).

9. Escobedo-Guajardo BL, Gonzalez-Salazar F, Palacios-Corona R, de la Cruz VM T, Morales-Vallarta M, Mata-Cardenas BD, Garza-Gonzalez JN, Rivera-Silva G, Vargas-Villarreal J. Trichomonas vaginalis acidic phospholipase A2: isolation and partial amino acid sequence. Acta Parasitol. 2013;58(4):519-26.

10. Sutton M, Sternberg M, Koumans EH, McQuillan G, Berman S, Markowitz L. The prevalence of Trichomonas vaginalis infection among reproductive-age women in the United States, 2001-2004. Clin Infect Dis. 2007;45(10):1319-26.

11. Zhang Z, Kang L, Wang W, Zhao X, Li Y, Xie Q, Wang S, He T, Li H, Xiao T, et al. Prevalence and genetic diversity of Trichomonas vaginalis clinical isolates in a targeted population in Xinxiang City, Henan Province, China. Parasit Vectors. 2018;11(1):124.

12. Liu J, Feng $M$, Wang $X, F u Y, M a ~ C$, Cheng $X$. Unique Trichomonas vaginalis gene sequences identified in multinational regions of Northwest China. Biosci Trends. 2017;11(3):303-7.

13. Yang S, Zhao W, Wang H, Wang Y, Li J, Wu X. Trichomonas vaginalis infection-associated risk of cervical cancer: a meta-analysis. Eur J Obstet Gynecol Reprod Biol. 2018;228:166-73.

14. Edwards T, Burke P, Smalley H, Hobbs G. Trichomonas vaginalis: clinical relevance, pathogenicity and diagnosis. Crit Rev Microbiol. 2016;42(3):40617.

15. Schumann JA, Plasner S: Trichomoniasis. In: StatPearls. edn. Treasure Island (FL): 2019.

16. Sheele JM, Crandall CJ, Arko BL, Vallabhaneni M, Dunn CT, Chang BF, Fann $P$, Bigach $M$. The OSOM(R) Trichomonas test is unable to accurately diagnose Trichomonas vaginalis from urine in men. Am J Emerg Med. 2019; 37(5):1002-3.

17. Nateghi Rostami M, Hossein Rashidi B, Habibi A, Nazari R, Dolati M. Genital infections and reproductive complications associated with Trichomonas vaginalis, Neisseria gonorrhoeae, and Streptococcus agalactiae in women of Qom, Central Iran. Int J Reprod Biomed. 2017;15(6):357-66.

18. Tsang SH, Peisch SF, Rowan B, Markt SC, Gonzalez-Feliciano AG, Sutcliffe S, Platz EA, Mucci LA, Ebot EM. Association between Trichomonas vaginalis and prostate cancer mortality. Int J Cancer. 2019;144(10):2377-80.

19. Mielczarek E, Blaszkowska J. Trichomonas vaginalis: pathogenicity and potential role in human reproductive failure. Infection. 2016:44(4):447-58.

20. Muzny CA, Burkholder GA, Fry KR, Austin EL, Schwebke JR. Trichomonas vaginalis nucleic acid amplification testing at an urban HIV clinic. Sex Transm Dis. 2016;43(8):483-8. 
21. Asmah RH, Agyeman RO, Obeng-Nkrumah N, Blankson H, Awuah-Mensah G, Cham M, Asare L, Ayeh-Kumi PF. Trichomonas vaginalis infection and the diagnostic significance of detection tests among Ghanaian outpatients. BMC Womens Health. 2018;18(1):206.

22. Adjei C, Boateng R, Dompreh A, Okyere B, Owiredu EW. Prevalence and the evaluation of culture, wet mount, and ELISA methods for the diagnosis of Trichomonas vaginalis infection among Ghanaian women using urine and vaginal specimens. Tropical Med Health. 2019;47:33.

23. Nabweyambo S, Kakaire O, Sowinski S, Okeng A, Ojiambo H, Kimeze J, Najjingo I, Bwanga F. Very low sensitivity of wet mount microscopy compared to PCR against culture in the diagnosis of vaginal trichomoniasis in Uganda: a cross sectional study. BMC Res Notes. 2017;10(1):259.

24. Testardini P, Vaulet ML, Entrocassi AC, Menghi C, Eliseht MC, Gatta C, Losada M, Touzon MS, Corominas A, Vay C, et al. Optimization of Trichomonas vaginalis diagnosis during pregnancy at a university hospital, Argentina. Korean J Parasitol. 2016;54(2):191-5.

25. Noh CS, Kim SS, Park SY, Moon HS, Hong Y, Ryu JS. Comparison of two PCR assays for Trichomonas vaginalis. Korean J Parasitol. 2019;57(1):27-31.

26. Fonseca THS, Oliveira FMS, Alacoque M, Rocha MI, Leite HV, Santos JFG, Busatti $\mathrm{H}$, Caliari MV, Gomes MA. Immunocytochemistry improving the diagnosis of Trichomonas vaginalis infections. Biomed Res Int. 2017;2017: 5642535.

27. Mori Y, Notomi T. Loop-mediated isothermal amplification (LAMP): a rapid, accurate, and cost-effective diagnostic method for infectious diseases. J Infection Chemother. 2009;15(2):62-9.

28. Mori Y, Kanda H, Notomi T. Loop-mediated isothermal amplification (LAMP): recent progress in research and development. J Infect Chemother. 2013; 19(3):404-11.

29. Alderete JF, Garza GE. Specific nature of Trichomonas vaginalis parasitism of host cell surfaces. Infect Immun. 1985;50(3):701-8.

30. Espiritu CAL, Justo CAC, Rubio MJ, Svobodova M, Bashammakh AS, Alyoubi AO, Rivera WL, Rollon AP, O'Sullivan CK. Aptamer selection against a Trichomonas vaginalis adhesion protein for diagnostic applications. ACS Infect Dis. 2018;4(9):1306-15.

31. Garcia AF, Chang TH, Benchimol M, Klumpp DJ, Lehker MW, Alderete JF. Iron and contact with host cells induce expression of adhesins on surface of Trichomonas vaginalis. Mol Microbiol. 2003;47(5):1207-24.

32. Garber GE: The laboratory diagnosis of Trichomonas vaginalis. 2016.

33. Spence MR. Epidemiology of sexually transmitted diseases. Sex Transm Dis. 1989;16(3):453-66.

34. Lockhart A, Psioda M, Ting J, Campbell S, Mugo N, Kwatampora J, Chitwa M, Kimani J, Gakure A, Smith JS: Prospective Evaluation Of Cervico-Vaginal Self And Cervical Physician-Collection For The Detection Of Chlamydia Trachomatis, Neisseria gonorrhoeae, Trichomonas Vaginalis, And Mycoplasma Genitalium Infections. Sex Transm Dis:2018.

35. Sonkar S, Wasnik K, Mishra P, Mittal P, Kumar A, Suri J, Saluja D: Prevalence and co-infection study ofChlamydia trachomatis,Neisseria gonorrhoeae, andTrichomonas vaginalisamong symptomatic women using PCR assay. BMC Infect Dis. 2014. 14(3 Supplement):P5.

36. Carrillo-Ávila JA, Serrano-García ML, Fernández-Parra J, Sorlózano-Puerto A, Navarro-Marí JM, Stensvold CR, Gutiérrez-Fernández J. Prevalence and genetic diversity of Trichomonas vaginalis in the general population of Granada and co-infections with Gardnerella vaginalis and Candida species. 2017;66(10):1436.

37. Luo L, Reilly KH, Xu JJ, Wang GX, Ding GW, Wang N, Wang HB. Prevalence and correlates of Trichomonas vaginalis infection among female sex workers in a city in Yunnan Province, China. Int J STD AIDS. 2016;27(6):469-75.

38. Mori Y, Nagamine K, Tomita N, Notomi T. Detection of loop-mediated isothermal amplification reaction by turbidity derived from magnesium pyrophosphate formation. Biochem Biophys Res Commun. 2001;289(1):150-4.

39. Curtis KA, Rudolph DL, Owen SM. Sequence-specific detection method for reverse transcription, loop-mediated isothermal amplification of HIV-1. J Med Virol. 2009;81(6):966-72.

40. Njiru ZK, Mikosza AS, Matovu E, Enyaru JC, Ouma JO, Kibona SN, Thompson RC, Ndung'u JM. African trypanosomiasis: sensitive and rapid detection of the sub-genus Trypanozoon by loop-mediated isothermal amplification (LAMP) of parasite DNA. Int J Parasitol. 2008;38(5):589-99.

41. Njiru ZK, Ouma JO, Enyaru JC, Dargantes AP. Loop-mediated isothermal amplification (LAMP) test for detection of Trypanosoma evansi strain B. Exp Parasitol. 2010;125(3):196-201.

42. Wang L, Li L, Alam MJ, Geng Y, Li Z, Yamasaki S, Shi L. Loop-mediated isothermal amplification method for rapid detection of the toxic dinoflagellate Alexandrium, which causes algal blooms and poisoning of shellfish. FEMS Microbiol Lett. 2008;282(1):15-21.

43. Karanis $P$, Thekisoe O, Kiouptsi K, Ongerth J, Igarashi I, Inoue N. Development and preliminary evaluation of a loop-mediated isothermal amplification procedure for sensitive detection of cryptosporidium oocysts in fecal and water samples. Appl Environ Microbiol. 2007;73(17):5660-2.

44. Toye B, Woods W, Bobrowska M, Ramotar K. Inhibition of PCR in genital and urine specimens submitted for chlamydia trachomatis testing. J Clin Microbiol. 1998;36(8):2356-8.

45. Huppert JS, Mortensen JE, Reed JL, Kahn JA, Rich KD, Miller WC, Hobbs MM. Rapid antigen testing compares favorably with transcription-mediated amplification assay for the detection of Trichomonas vaginalis in young women. Clin Infect Dis. 2007;45(2):194-8.

46. Lawing LF, Hedges SR, Schwebke JR. Detection of trichomonosis in vaginal and urine specimens from women by culture and PCR. J Clin Microbiol. 2000;38(10):3585-8.

47. Fernandez-Soto P, Gandasegui J, Carranza Rodriguez C, Perez-Arellano JL, Crego-Vicente B, Garcia-Bernalt Diego J, Lopez-Aban J, Vicente B, Muro A. Detection of Schistosoma mansoni-derived DNA in human urine samples by loop-mediated isothermal amplification (LAMP). PLoS One. 2019;14(3): e0214125.

48. Tanner NA, Zhang Y, Evans TC Jr. Simultaneous multiple target detection in real-time loop-mediated isothermal amplification. Biotechniques. 2012;53(2): $81-9$.

49. Reyes JC, Solon JA, Rivera WL. Development of a loop-mediated isothermal amplification assay for detection of Trichomonas vaginalis. Diagn Microbiol Infect Dis. 2014;79(3):337-41.

50. Adao DE, Rivera WL. Loop-mediated isothermal amplification (LAMP) assay for the rapid detection of the sexually-transmitted parasite, Trichomonas vaginalis. Annals Parasitol. 2016;62(1):25-31.

51. Goo YK, Shin WS, Yang HW, Joo SY, Song SM, Ryu JS, Kong HH, Lee WK, Chung DI, Hong Y. Loop-mediated isothermal amplification targeting actin DNA of Trichomonas vaginalis. Korean J Parasitol. 2016;54(3):329-34

52. Garcia AF, Alderete J. Characterization of the Trichomonas vaginalis surfaceassociated AP65 and binding domain interacting with trichomonads and host cells. BMC Microbiol. 2007;7:116.

53. Notomi T, Okayama H, Masubuchi H, Yonekawa T, Watanabe K, Amino N, Hase T. Loop-mediated isothermal amplification of DNA. Nucleic Acids Res. 2000;28(12):E63.

54. Zhang M, Liu Y, Chen L, Quan S, Jiang S, Zhang D, Yang L. One simple DNA extraction device and its combination with modified visual loop-mediated isothermal amplification for rapid on-field detection of genetically modified organisms. Anal Chem. 2013;85(1):75-82.

55. Caliendo AM, Jordan JA, Green AM, Ingersoll J, Diclemente RJ, Wingood GM. Real-time PCR improves detection of Trichomonas vaginalis infection compared with culture using self-collected vaginal swabs. Infect Dis Obstet Gynecol. 2005;13(3):145-50.

56. Queza MI, Rivera WL. Diagnosis and molecular characterization of Trichomonas vaginalis in sex workers in the Philippines. Pathogens Global Health. 2013;107(3):136-40.

57. Kaneko H, Kawana T, Fukushima E, Suzutani T. Tolerance of loop-mediated isothermal amplification to a culture medium and biological substances. J Biochem Biophys Methods. 2007;70(3):499-501.

58. Goto M, Honda E, Ogura A, Nomoto A, Hanaki K. Colorimetric detection of loop-mediated isothermal amplification reaction by using hydroxy naphthol blue. BioTech. 2009;46(3):167-72.

59. Tao ZY, Zhou HY, Xia H, Xu S, Zhu HW, Culleton RL, Han ET, Lu F, Fang Q, Gu YP, et al. Adaptation of a visualized loop-mediated isothermal amplification technique for field detection of plasmodium vivax infection. Parasit Vectors. 2011;4:115.

\section{Publisher's Note}

Springer Nature remains neutral with regard to jurisdictional claims in published maps and institutional affiliations. 